\title{
Social Media Changing Inter-Personal Relationship Among Urban Couples
}

\author{
Hasanbir Virk \\ Amity University, Noida, India
}

\begin{abstract}
Social media is playing a vital role in urban life and with the young working students and married couples. As this medium has grown over a last few decades, most popular among youth. The social media once need for sharing views and short notes, chatting, initially through Facebook, Orkut, Yahoo and other mailing apps has grown up to the current stage over the period of last thirty years and plus. The trend of the social media started changing in the last more than a decade when its impacts on the social life become more vigilant.
\end{abstract}

Key words: $\quad$ Social Media, Interpersonal Relations, Sociology

\section{Introduction}

Once medium to express and share views and your emotions has slowly transformed our thought process- as the increasing use of the modern tools and the growing information Technology, the use of modern Information Technology has started interfering with your input data through Algorithms and Artificial Intelligence(AI), now your social media not only understands your choices, requirements, behavior and your hidden emotions that to without your notice of any of these activities. This data is stored, copied, and put to the use of steeling and robbing your private and personal information which are vulnerable for your life carrier and interpersonal relationships. As any misuse of the data may result in your loss of carrier, growth, your inter-personal relations and may tarnish your image and it also invites different marketing approach to buy and sale certain products and services.

\section{Impacts of New Era Technology}

The new era of Technology has changed the face of not only how we express our feelings, thoughts, but also has started interfering in our privacy. The Information and the secret which are not disclosed to closest of your friend, relative and your spouse is not only known to this media platform but it can use these data as information to force your decision to change to some particular option, they can break the relations, they can change the image and not only the image, they can change the face of politics. They can create or tarnish image of an individual, group, corporate, or even an elected govt
This media can change your choices, emotions, your options, and at large plays with your brain to port you to some particular direction which may result as-

- A collapse of a elected govt.

- To create mass level riots and public gathering for one particular agenda.

- To change public opinion for one individual, actor, politician, corporate, an NGO.

- Affecting your buying behavior is a small point.

- Also this can harm your natural instincts for a natural relation/work.

- Anxiety and depression is a common factor attached to its excess of use.

- Hysteria Suicidal emotions and Violent behavior may be the result of long term exposure on above average of excessive use of social media.

- Pseudo-Psychosis for something worst expected to happen which is very common.

\section{Effects of Social Media}

All the years in the last one decade the effect of social media an on expression of speech was on top of the list on society, govt., media debates. The social Activists and Researchers raised alarm for immediate action to save privacy and our precious relations from this trap. The trap is so well planned that the victims are the brand ambassadors of the social media utility. 
World over corporate, govt., Activists has shown their concern for this foul play.-

- Safety of your personal data is at stake.

- Your cell-phone is your worst enemy. He is always listening to every single world you speak, it not only listens to you, it can take your pictures and videos and above all it can steel your data with the help of some manufacturing codes inbuilt in its hardware and through the use of certain apps which keeps on doing research on your device storage system.

- Your personal passwords and passwords of your delicate financial data is at risk and at mercy of the valuable apps and manufacturers of the cellphone devices.

- Miss use of your data and opinion can create unrest of your personal relations and in the society at the large.

- Miss use of this data is the modern business model of the digital marketing platforms for exploring various purposes- political, sale-purchase, entertainment, fraud and miss caught, etc.

\section{The threats to be faced}

Besides all these effects and foul planning the biggest threat is not only to national peace harmony in our society alone, our family life, inter personal relationships, are worst hit area. The couples have their different identities and in our society they are expected to find out their common interest, develop love, affection and are expected to respect each other, as the base of the family part is love and trust on each other. Inter-personal relations are vulnerable to the spread of social media and electronic gadgets.

The work environment is already the vital source of anxiety and stress, the excessive use of social media can create mess in this situation as modern era allow limited hours you spend at home with your relations and in-spite of the limit of the time, couples choose to stay connected over the social media with their individual friends and groups instead of spending time with your spouse and family.

This situation start playing a cause of your unrest and long term exposure to this situation can affect the precious relations and inter-personal peace harmony.

\section{Root of Problem and Recommendations}

When we study the basic root of the problem the finding suggests the less interaction and understanding between each other created the mess-

- The behavioral change resulted due to excessive use of the electronic gadgets and social media kicked the peace of your mind.

- Anxiety, stress, depression, with work load, and less sharing habit with your partner became the cause of your mental and physical unrest.

- Fear Psychosis Phobias are commonly reported in studies where the patients suffer with fear of something worse is expecting.

- Hysteria, Suicidal emotions, violent behavior plays big role in inter-personal divide i.e 'Divorce' and is common cause of suicide among young couples.

- Impulse buying on social media advertisements while ignoring your affordability also become issue of debate and often leads to the trigger of dividelDomestic violence and divorce.

- Less trust on partner and spouse is a new trend as your social media behavior may create a false image and even someone can miss use this situation to land you on wrong decision or action.

- It is evident from the recent surveys in domestic violence and divorce cases sharp increase is reported in last more than a decade- the marriage cancellers, women helpline, family courts, mediation cells, has reported that one think is common that increasing use or miss use of social media has played a vital role in dispute creation besides other factors.

- Lifestyle disorders are on all times high as they are giving lesser time to physical workout and all credit goes to our engagement with social media till late night.

- $\quad$ Pornography and violent movies are common among searches and sharing images in young adults, this dirty practice is one of the root cause of less trust and understanding.

\section{Conclusion}

the problem is well understood that quantum of the problem is also noted now comes the solution as to what is needed and 
how we can control the problem and the situation at large. Following are the way outs suggested by the activist, experts and researchers that implementation of these points may protect the precious interpersonal relations and the marriage institutions.-

- Caring and sharing of the love and affection should be motto to develop the trust in inter-personal relations.

- Limited time on social media is the best bet and keeping your partner and spouse in your friends list and the family group is also suggested.

- Proper counseling cells to explore the problem areas and to suggest the remedy before the on-set of the vital symptoms to work out the remedial work. The family court, women helpline, mediation cells, should work as a team to protect the marriage institution for larger society intrust.

- All anxiety, depression, stress symptoms to be addressed professionally as early as possible to save human lives.

- Initial symptoms of stress and fear psychosis should be reported to the health specialist to initiate the treatment.

- $\quad$ Suicidal emotionslviolent behavior must be reported to health specialist and authorities timely to initiate corrective measures.

- Impulse buying should be avoided to protect financial security and trust of your partner.

- $\quad$ Spend time with family, friends, and your spouse. Also work out together to manage day to day stress on work.
[4]. Eisenmann, M., O’Neil, M. \& Geddes, D. (2015). An Examination of the Validity, Reliability and Best Practices Related to the Standards for Traditional

[5]. Elisabetta, C. (2016). Social Media in Southeast Turkey, London: UCL Press

[6]. Kendall, D. (2016). Sociology in our times (10 ed.). Boston, Ma: Cengage Learning.

[7]. Media. Research Journal of the Institute for Public Relations. 2(1), 1-28. Retrieved on 19th June, 2016 from http://prjournal.instituteforpr.org/wpcontent/uploads/Eisenmann_ONeil_Geddes_REVI SIONS_V2_01_07_2015-1.pdf.

[8]. Olufadi, Y. (2016). Social networking time use scale SONTUS: a new instrument for measuring the time spent on the social networking sites. Elsevier Telematics and Informatics, 33, 452-471. https://doi.org/10.1016/j.tele.2015.11.002

[9]. Taylor, M., Wells, G., Howell, G., \& Raphael, B. (2012). The role of social media as psychological first aid as a support to community resilience building. The Australian Journal of Emergency Management, 27 (1), 20-26. Retrieved from http://www.em.gov.au/publications/australianj.../ on 27th June, 2016.

[10]. Women Helpline Data Delhi Govt. Published in multiple resources in multiple months/years

[11]. Proceedings of "Domestic Violence sharp increase in cases" from Delhi High Court 2017.

[12]. Data of Delhi Family Courts registration of new cases taken from multiple resources.

[13]. Man Helpline Data of last five years (2010 onwards).

[14]. Multiple Media Reports of CNN, ZEE News and other national news publishers.

\section{References}

[1]. Ante-Contreras, D. (2016). Distracted parenting: how social media affects parent-child attachment (Doctoral dissertation). Retrieved from http://scholarworks.lib.csusb.edu/etd

[2]. Bowe, G. (2010). Reading romance: The impact Facebook rituals can have on romantic relationship. Journal of Comparative Research in Anthropology and Sociology, 1(2), 61-77. Retrieved on 22nd November, $2016 \quad$ from didattica.uniroma2.it/assets/uploads/corsi/143781/ Analysing_social_networks.pdf.

[3]. Britt, Milissa. (2017). Effects of Social Media Use On Interpersonal Relationship Satisfaction. 